Marquette University

e-Publications@Marquette

Library Faculty Research and Publications

Library (Raynor Memorial Libraries)

$1-1-2001$

\title{
Cultivating Partnerships/Realizing Diversity
}

Janice Simmons-Welburn

Marquette University, janice.welburn@marquette.edu

William C. Welburn

Marquette University, william.welburn@marquette.edu

Accepted version. Journal of Library Administration, Vol. 33, No. 1/2 (2001): 5-19. DOI. C 2001 Taylor \& Francis (Haworth Press). Used with permission.

Janice Simmons-Welburn was affiliated with the University of Iowa Libraries at the time of publication. 


\title{
Cultivating Partnerships/Realizing Diversity
}

\author{
Janice Simmons-Welburn \\ Raynor and Memorial Libraries, Marquette University \\ Milwaukee, WI
}

William C. Welburn

Office of the Provost Research and Publications, Marquette University

Milwaukee, WI

\begin{abstract}
Academic librarians should not only seek methods for continuous learning about an increasingly diverse college student body, they are encouraged to pursue partnerships with campus agencies that work directly with students, especially those charged with building a diverse community of students. The authors present two examples to illustrate strategies-in-action.
\end{abstract}

\section{Introduction}

As the overall population of the United States continues to change in its ethnic constitution, ${ }^{1}$ the nation's colleges and universities are challenged to create strategies that enhance access and expand the educational opportunities for an increasingly diverse citizenry. ${ }^{2}$ The nation's populations have always been, to paraphrase historian Stephanie Grauman Wolf, ${ }^{3}$ as varied as its lands, yet only in the past three decades - following the tumultuous movement for civil rights - 
have colleges and universities adopted new approaches that respond to anticipated increases in enrolling diverse populations of students. ${ }^{4}$

These strategies intend to assure success among students seeking access to associate, baccalaureate, graduate, and professional degree and certification programs in a society imagined to be ever widening in its scope of opportunities. ${ }^{5}$ The educational continuum through which today's students pass resembles, as William Bowen and Derek Bok put it, a river:

It is more helpful to think of the nurturing of talent as a process akin to moving down a winding river, with rock-strewn rapids and slow channels, muddy at times and clear at others. Particularly when race is involved, there is nothing simple, smooth, or highly predictable about the education of young people. ${ }^{6}$

Along the winding river, many colleges and universities continue to devise initiatives administrators hope will respond to the educational needs of emerging populations and, in particular, minority and low income/first-generation students. They intend to reduce the effects of disparities in educational background and performance, improve institutional climate, and encourage minority and low income/firstgeneration students to stay in the rush of the water, persisting not only through the baccalaureate degree but also to pursue advanced graduate and professional study. ${ }^{7}$ Such initiatives are abundant-at community and liberal arts colleges and at public and private research universities alike - and when successful yield favorable results. ${ }^{8}$

An examination of the potential for cultivating partnerships between academic libraries and campus academic or academic support services provides a backdrop for further consideration of the value of realizing diversity in American institutions of higher learning. ${ }^{9}$ The support that academic libraries can give to programs designed to develop traditionally underrepresented students in higher education is worth cultivating, realizing that opportunities to collaborate across the complex institutional structures of colleges and universities are often difficult to accomplish. Yet becoming information literate can be an integral part of higher learning, and accordingly can serve to be an integral part of the responsibility of an institution in enabling students' pursuit of success in reaching goals well beyond the academy. ${ }^{10}$ 


\section{The Intellectual Ecosystem of Undergraduate Education}

Despite the observable differences between types of colleges and universities-size, affiliation, resource support, degree offerings, to name a few-there are important threads that tie one sector of higher education to the others. ${ }^{11}$ While findings in the 1998 Boyer Commission report on reinventing undergraduate education are intended to challenge research universities, they are applicable to all of higher education. Particularly noteworthy is the Commission's characterization of the campus as an intellectual ecosystem:

The interaction of many kinds of stimuli creates at a university a special kind of intellectual environment, with the health of the whole a manifestation of the health of each part. That environment should become an intellectual ecosystem [emphasis added]. Universities are communities of learners, whether those learners are astrophysicists examining matter in the far reaches of space or freshmen new to an expanded universe of learning. The shared goals of investigation and discovery should bind together the disparate elements to create a sense of wholeness. ${ }^{12}$

Today's academic libraries are challenged to articulate a role in the campus ecosystem for student learning and academic development. Academic library leaders can begin by promoting continuous learning among staff about how college affects undergraduate students both in and out of the classroom. No effort will be made here to review the substantial body of research and commentary on college student development; ${ }^{13}$ yet, two important questions rise to the surface of the following discussion about student diversity:

- What are the transitions and impediments that shape the river for minority and low income/first-generation college students, given the complexities of the campus intellectual ecosystem?

- What opportunities exist for collaboration between academic libraries and other agencies of diversity on college and university campuses that shape a more effective institutional response to the requirements for student learning in an information age?

Journal of Library Administration, Vol 33, No. 1/2 (2001): pg. 5-19. DOI. This article is @ Taylor \& Francis (Routledge) and permission has been granted for this version to appear in e-Publications@Marquette. Taylor \& Francis (Routledge) does not grant permission for this article to be further copied/distributed or hosted elsewhere without the express permission from Taylor \& Francis (Routledge). 
What follows is an attempt to join issues common to higher educational institutions, regardless of differences in academic or organizational mission, environment or culture, that focus on the learning experiences of undergraduates. It is an attempt at setting a stage to think about what opportunities exist for partnerships between academic libraries and academic support services. This paper argues that collaborative work will ensure a sustainable presence for information literacy in academic support services programs. Two examples will be given from experiences at the University of Iowa as evidence of the value of partnerships and collaborative work between units in academic settings as a way of supporting institutional goals.

\section{The Effect of College on Students}

Researchers often point to disparities in academic preparedness of students seeking entry into higher education. Disparities are quite often attributed to individual or family-related experiences, or to educational background and experience in schools. ${ }^{14}$ Some researchers have found connections between academic achievement and access to Advanced Placement (AP) and honors courses, and involvement in extracurricular activities. ${ }^{15}$ Researchers from the American College Testing Program (ACT) relate such factors to "students' choices of high school course work and grades they earn in those courses, which, in turn, are strongly related to ACT scores, ${ }^{16}$ still a major determinant of selectivity in college admissions. A U.S. Department of Education study found that "the impact of a high school curriculum of high academic intensity and quality on [baccalaureate] degree completion is far more pronounced-and positively-for African-American and Latino students than any other pre-college indicator of academic resources."17 They continued:

Academic Resources . . . produce a much steeper curve toward bachelor's degree completion than does socioeconomic status. Students from the lowest two SES (Socioeconomic Status) quintiles who are also in the highest Academic Resources quintile earn bachelor's degrees at a higher rate than a majority of students from the top SES quintile. ${ }^{18}$

Socioeconomic disparities define the reality of K-12 education, of what Jonathan Kozol called the savage inequalities of American school systems, and race still seems to matter in access to quality 
schooling even when controlled for socioeconomic status. ${ }^{19}$ According to student development scholar Patrick Terenzini, first-generation college students differ:

In a number of ways from that of their traditional peers, and the differences suggest potential learning problems ahead for first-generation students . . . [who are] more likely to come from low-income families, to be Hispanic, to have weaker cognitive skills [in reading, math, and critical thinking], to have lower degree aspirations, and to have been less involved with peers and teachers in high school . . . [moreover they] tend to have more dependent children, expect to take longer to complete their degree programs, and report receiving less encouragement from their parents to attend college ... . the combined portrait is one of students at academic risk. ${ }^{20}$

Part of the road ahead in resolving disparities in academic preparation is a required shift in attention to the transitions from high schools to colleges and from two-to four-year institutions. Bridging programs or collaborations between high schools, community colleges, and four-year colleges, take on special significance as they provide systematic and comprehensive academic support and build connections between students and faculty. ${ }^{21}$ Some initiatives in higher education that have been funded by federal agencies, such as the U.S. Department of Education's TRIO Programs, ${ }^{22}$ the National Science Foundation's Alliance for Minority Participation in Science (AMPS), and the National Institutes of Health bridging programs, give special attention to educational needs of first-generation college students.

Persistence-especially among students of color-also appears to be related to climate and aspirations. Research by Sylvia Hurtado on the institutional climate for Latino students concluded that an improved institutional climate, one that is aware and knowledgeable of Latino culture and is less hostile to the presence and expressions of Latino students, faculty and staff, is strongly associated with successful educational attainment among Latino students. Latino students possessing academic strengths do appear to seek acceptance, and therefore are most receptive to a welcoming climate. ${ }^{23}$ Alberto Cabrera and his colleagues found that for all students, "exposure to a campus climate of prejudice and intolerance lessens commitment to the institution and, indirectly, weakens decisions to persist." 24 In other

Journal of Library Administration, Vol 33, No. 1/2 (2001): pg. 5-19. DOI. This article is @ Taylor \& Francis (Routledge) and permission has been granted for this version to appear in e-Publications@Marquette. Taylor \& Francis (Routledge) does not grant permission for this article to be further copied/distributed or hosted elsewhere without the express permission from Taylor \& Francis (Routledge). 
NOT THE PUBLISHED VERSION; this is the author's final, peer-reviewed manuscript. The published version may be accessed by following the link in the citation at the bottom of the page.

words, a chilly climate affects all students and is detrimental to their academic progress.

There is also a general perception that minority and low income/first-generation undergraduates are especially hampered by lower aspirations than other students, that ill-focused aspirations affect persistence, graduation rates, and decisions to pursue graduate education. Viewed another way, the perception of low aspirations closely resembles what psychologist Claude Steele refers to as stereotype threat, a "situational threat that . . . can affect the members of any group about whom a negative stereotype exists." 25 The perception of lower aspirations among both minority and lowincome/first-generation students may obfuscate self-doubt affecting both groups, doubt that leaves a misperception about educational goals and aspirations.

Mentoring, a "dynamic reciprocal relationship in a work environment between an advanced career incumbent and a beginner aimed at promoting the career development of both, ${ }^{26}$ can be an effective method of redressing low aspirations. Academic mentoring programs for minority students are commonplace, especially among selective colleges and universities that wish to establish relationships between undergraduate students and faculty in students' chosen areas of academic interest, thereby favorably contributing to students' socialization in a given discipline. ${ }^{27}$ Bowen and Bok also maintain that institutional interventions, such as undergraduate research and intensive academic programs, boost the efforts of colleges and universities to increase the number of students of color who choose graduate or professional study. ${ }^{28}$ Results of mentoring programs, such as the Mellon Minority Undergraduate Program, the Myerhoff Scholars Program at the University of Maryland-Baltimore County, and the Committee on Institutional Cooperation's (CIC) Summer Research Opportunities Programs (SROP), all point to successful outcomes, including higher involvement in graduate education. ${ }^{29}$

Additionally, the U.S. Department of Education, Office of TRIO Programs has expanded its menu of federally funded academic support services programs for low income/first-generation students by developing Ronald McNair Scholars Programs serving 3,641 students on 156 college and university campuses. McNair scholars are

Journal of Library Administration, Vol 33, No. 1/2 (2001): pg. 5-19. DOI. This article is @ Taylor \& Francis (Routledge) and permission has been granted for this version to appear in e-Publications@ Marquette. Taylor \& Francis (Routledge) does not grant permission for this article to be further copied/distributed or hosted elsewhere without the express permission from Taylor \& Francis (Routledge). 
undergraduate students who receive the individual attention of faculty mentors, who also work with the students on research projects. ${ }^{30}$

\section{A Typology of Institutional Initiatives}

Colleges and universities have responded to factors with different initiatives designed to reduce if not eliminate disparities. ${ }^{31}$

- Pre-college programs. Programs for middle and high school students, designed to encourage college enrollment and, in some cases, science majors. Such programs include Howard Hughes Life Sciences Programs, high school summer science training programs, and Upward Bound.

- Bridging programs. Programs designed to assist in both academic and social transition from high school to college. Examples include Upward Bound, AMPS, and other transition programs that work primarily if not exclusively with low income/first-generation students.

- Educating undergraduates. Programs that combine "rigor and optimism"32 to not only improve performance but inspire students to pursue graduate study. Examples include Mellon Minority Undergraduate Programs at private colleges and universities, the Meyerhoff Academy at the University of Maryland-Baltimore, SROP at Big 10 universities, and Ronald E. McNair Scholars programs.

- Predoctoral programs. Programs that prepare new graduate students for the rigor of graduate education. Examples can be found at the Universities of Michigan and Illinois.

\section{How Libraries Can Respond: Cultivating Partnerships}

Unfortunately, neither the role of the academic library nor the quest for an information literate student body figures prominently in discussions on the effect of college on students' cognitive growth and academic success. Terms such as libraries, library instruction, information seeking, or information literacy do not appear in the index to Terenzini and Pascarella's 800 page review of twenty years of research on the development of college students. ${ }^{33}$ Yet, students enroll in colleges and universities with far ranging pre-college educational experiences and academic preparation, and their exposure to 
academic resources varies substantially. Likewise, their access to information in support of education varies by resources available, including access to libraries and to resources available via the Internet. School systems across the United States vary substantially, and many are without the resources to provide their students with what Carol Kuhlthau called an information-age school library.

The central goal of the restructured library media program is to develop ability in the process of learning from a variety of sources of information in each subject in the curriculum . . . this is the essential piece to the puzzle that is missing in many efforts to restructure education of the twenty-first century. Failing to prepare students for learning in an information-rich environment is to fail to meet the challenge of education today. ${ }^{34}$

An information literate student is "one who can recognize when information is needed and has the ability to locate, evaluate, and effectively use the needed information." 35 If the purpose of instructional activities in academic libraries is to enhance the quality of student learning by incorporating information literacy, then how do libraries intersect information literacy with the requirements for student learning? The answer to this question must also take into account disparities in exposure to information resources and other academic resources that compose the mosaic of educational and sociocultural experiences of today's undergraduates.

We propose that libraries cultivate partnerships with those campus programs that are directly responsible for diversifying our student bodies. Libraries can have a significant impact on preparing students for their desired futures by first recognizing the importance of programmatic interventions, then persuading program administrators of the benefits of exposure to information-rich environments to students' academic training.

\section{Cultivating Partnerships at the University Of Iowa: Two Examples}

Two examples-one involving a program for high school students and the other a summer undergraduate research program - illustrate how the University of Iowa Libraries has worked with other offices on campus to cultivate partnerships and introduce information literacy.

Journal of Library Administration, Vol 33, No. 1/2 (2001): pg. 5-19. DOI. This article is @ Taylor \& Francis (Routledge) and permission has been granted for this version to appear in e-Publications@Marquette. Taylor \& Francis (Routledge) does not grant permission for this article to be further copied/distributed or hosted elsewhere without the express permission from Taylor \& Francis (Routledge). 
NOT THE PUBLISHED VERSION; this is the author's final, peer-reviewed manuscript. The published version may be accessed by following the link in the citation at the bottom of the page.

\section{Upward Bound}

In the first example, University of Iowa Libraries staff were able to negotiate an information literacy component to the university's Upward Bound program. Upward Bound is one of eight outreach and academic support programs known as TRIO and administered by the U.S. Department of Education designed to reach middle and high school students from low-income households and encourage their participation in higher education. Created by the 1964 Educational Opportunity Act and reauthorized under subsequent Higher Education Acts, Upward Bound specifically prepares high school students for college.

Many college and university libraries have developed limited engagement with Upward Bound. At the University of Iowa, however, the Libraries moved beyond traditional, short-term instruction to develop a more integrated program with Upward Bound staff that would employ concepts of information literacy. The Libraries' goal in revising its pedagogical strategy was fundamentally epistemic; each session and each assignment represented a step toward greater knowledge and awareness of how to seek out, evaluate, and use information.

In practical terms, the Libraries had grown accustomed to offering a brief orientation and tour to Upward Bound students. In the early 1990s, the Libraries' diversity librarian began engaging Upward Bound staff in dialogue over the benefits of developing the information seeking skills of academically high-risk students, and as more library staff became involved, the partnership between Upward Bound and the Libraries in teaching the use of various information resources evolved. The Libraries first guided Upward Bound students through a series of skill-building experiences in information seeking using library resources over several sessions using the Information Arcade, the Libraries' technology-based teaching-learning center.

As library and Upward Bound staff worked together, instruction evolved from a library session to course-integrated teaching combined with library training sessions for Upward Bound teaching staff. The emphasis in the revised approach shifted from teaching library use to providing grounds for building individual knowledge on locating information in support of class assignments and other academic

Journal of Library Administration, Vol 33, No. 1/2 (2001): pg. 5-19. DOI. This article is @ Taylor \& Francis (Routledge) and permission has been granted for this version to appear in e-Publications@Marquette. Taylor \& Francis (Routledge) does not grant permission for this article to be further copied/distributed or hosted elsewhere without the express permission from Taylor \& Francis (Routledge) 
activities, independently analyzing results and refining search strategies, and seeking out sources to aid in using chosen information. Students gained exposure to a variety of accessible information resources, including the Libraries online information system and catalog, the Web, and printed sources found among the Libraries holdings.

The benefits of this partnership are manifold, yet three stand out. First, TRIO programs are strongly encouraged to involve students in new technologies. Given that much of the Libraries' mode of instructional delivery and goals of information literacy involves the use of information technologies, the Libraries' instructional design greatly enhances the Upward Bound program's charge. Second, Upward Bound can add to its arsenal of methods for supporting students in their transition from high school to college exposure not only the vastness of a college or university library but also how academic library systems can be effectively exploited to support coursework. ${ }^{36}$

Finally, by participating in Upward Bound and other TRIO programs, the Libraries became an active agency in academic socialization for students transitioning from high school to college. Libraries became actively involved in the lives and success of a significant number of students of color or low-income, first-generation pre-college students. As the Council for Opportunity in Education has observed,

Students in the Upward Bound program are four times more likely to earn an undergraduate degree than those students from similar backgrounds who did not participate in TRIO.

Nearly 20 percent of all Black and Hispanic freshmen who entered college in 1981 received assistance through the TRIO Talent Search or EOC programs.

Students in the TRIO Student Support Services program are more than twice as likely to remain in college than those students from similar backgrounds who did not participate in the program. ${ }^{37}$ 


\section{Summer Research Opportunities Program (SROP)}

Upward Bound is but one case in point of a program that has successfully bridged numerous students into higher education. The SROP is an example of an effort to encourage students to go higher in education by pursuing advanced graduate work, preferably research doctoral degrees. SROP, an idea that began in 1980 at Purdue University and was expanded to include other Big 10 schools, is now commonplace not only among research universities but also among liberal arts colleges and other types of institutions of higher education. ${ }^{38}$ Summer research program student participants are matched with faculty mentors to actively engage in the mentors' research. While largely concentrated in scientific disciplines (the sciences, engineering, and mathematics), summer research programs invite advanced undergraduate students from all disciplines where there are substantive research opportunities for an eight to ten week program that includes a research component as well as programming intended to prepare students for graduate school admissions.

Most student participants in the University of Iowa's SROP are not enrolled at the University; rather, they are working toward degrees at smaller, teaching-centered colleges with more limited access to the resources of a research university. As a second illustration of the value of collaboration, the Libraries began working with the University of Iowa Graduate College-the campus host of SROP-to incorporate elements of information literacy as a part of the student participants' experience. Given that students' time was largely consumed by research assignments, the Libraries and Graduate College sought a method of collaboration that would be relatively unobtrusive yet sustainable. Dispensing with a tour of the Main Library-which did not serve the interests of the science students-librarians created a Web site tailored to support the needs of student participants, including access to an array of discipline-specific, scholarly information resources on the Internet and in the Libraries, along with names, areas of expertise, and contact information for librarians covering the students' subject interests. A librarian introduced the Web page during the program's seminar, and the program director and teaching assistant prepared subsequent writing assignments that required use of the Web page and its various links. The Web page is retained during permission has been granted for this version to appear in e-Publications@Marquette. Taylor \& Francis (Routledge) does not grant permission for this article to be further copied/distributed or hosted elsewhere without the express permission from Taylor \& Francis (Routledge). 
the course of the subsequent academic year to enable students to continue to use it as an information resource.

Unlike the first example, the Libraries accepted that there was little time available to present in-depth instruction to SROP students. Yet traditional methods such as tours only inadequately prepared students for seeking information. In this illustration, linking resources in a form that is available to students when they need it and where they have access to it-in labs, the library, or from the computer cluster in the residence hall-resolved the dilemma.

Both examples illustrate how libraries learn to cultivate partnerships on campus in support of student learning. They show the importance of negotiating the library's role in programs designed to foster campus diversity using innovative pedagogical and technological approaches contingent upon different programmatic goals.

\section{Conclusion}

When one views the college campus as an intellectual ecosystem, there are numerous opportunities to cultivate partnerships between the library and campus agencies that can be enriched by teaching students strategies for locating, evaluating, and using information in response to a vast array of academic, professional, and personal needs. This is clearly understood by the academic library community, though less understood or accepted elsewhere in colleges and universities. Yet the disparity throughout the American K-12 educational system creates unequal footing at the doors of higher education. There is great benefit to enriching not only students' science and math skills, but also to increase students' capacity to use the information around them. Partnerships between libraries and other academic-centered programs may serve as agencies to, as historian Tom Holt wrote, "think for themselves and think creatively." 39

\section{References}

1. Jennifer Cheeseman Day, Population Projections of the United States by Age, Sex, Race, and Hispanic Origin 1995-2050, U.S. Bureau of the Census, Current Population Reports, P25-1130 (Washington, DC: GPO, 1996).

2. Eugene Y. Lowe, "Promise and Dilemma: Incorporating Racial Diversity in Selective Higher Education," in Promise and Dilemma: Perspectives on Racial Diversity in Higher Education, ed. Eugene Y. Lowe (Princeton, permission has been granted for this version to appear in e-Publications@Marquette. Taylor \& Francis (Routledge) does not grant permission for this article to be further copied/distributed or hosted elsewhere without the express permission from Taylor \& Francis (Routledge). 
NOT THE PUBLISHED VERSION; this is the author's final, peer-reviewed manuscript. The published version may be accessed by following the link in the citation at the bottom of the page.

NJ: Princeton University Press, 1999), 3. See also Does Diversity Make a Difference? Three Research Studies on Diversity in College Classrooms (Washington, DC: American Council on Education and American Association of University Professors, 2000), 1-2; Reaching the Top: A Report of the National Task Force on Minority High Achievement (New York: The College Board, 1999).

3. Stephanie Grauman Wolf, As Various as Their Lands: The Everyday Lives of Eighteenth Century Americans (New York: HarperCollins, 1993); Martha Farnsworth Richie, in a study for the Population Reference Bureau wrote, "The U.S. population has always been multiracial, and it is becoming even more diverse now than it was at its founding two centuries ago," see "America's Diversity and Growth: Signposts for the 21st Century," Population Bulletin 55 (2) (June 2000).

4. Does Diversity Make a Difference? 1.

5. The College Board, Reaching the Top, 11-12. See also Patricia Gandara and Julie Maxwell-Jolly, Priming the Pump: Strategies for Increasing the Achievement of Underrepresented Minority Undergraduates (New York: The College Board, December 1999).

6. William G. Bowen and Derek A. Bok, The Shape of the River: Long-Term Consequences of Considering Race in College and University Admissions (Princeton, NJ: Princeton University Press, 1998), 14.

7. Gandara, Priming the Pump; for an example of a program, see Uro Treisman, "Studying Students Studying Calculus: A Look at the Lives of Minority Mathematics Students in College," College Mathematics Journal 23 (November 1992): 362-72.

8. For instance, the Council for Opportunity in Education reported "over 1,900 TRIO Programs currently serve nearly 700,000 low-income Americans between the ages of 11 and 27." What is Trio, Council of Educational Opportunity Programs [online] available from http://www.trioprograms.org/home.html [cited 25 October 2000]. Bowen and Bok also describe exemplary programs at selective schools, see Bowen and Bok, Shape of the River, 86-90.

9. By academic support services, the authors refer to those non-academic units that administer or host academic programs for students. These include student support services programs, tutoring programs, and programs designed for academically at-risk students.

10. According to the American Library Association, Presidential Commission on Information Literacy, "To be information literate, a person must be able to recognize when information is needed and have the ability to locate, evaluate, and use effectively the needed information." American Library Association. Presidential Committee on Information Literacy. Final Report (Chicago: American Library Association, 1989)

Journal of Library Administration, Vol 33, No. 1/2 (2001): pg. 5-19. DOI. This article is @ Taylor \& Francis (Routledge) and permission has been granted for this version to appear in e-Publications@Marquette. Taylor \& Francis (Routledge) does not grant permission for this article to be further copied/distributed or hosted elsewhere without the express permission from Taylor \& Francis (Routledge). 
NOT THE PUBLISHED VERSION; this is the author's final, peer-reviewed manuscript. The published version may be accessed by following the link in the citation at the bottom of the page.

[online] available from http://www.ala.org/acrl/nili/ilit1st.html [cited 25 October 2000].

11. The Carnegie Foundation's Classification of Institutions of Higher Education, under revision at the time of this writing, provides one method of understanding the differences between types of colleges and universities. It is heavily based on degrees granted, affiliation, mission and other institutional characteristics. [online] available from http://www.carnegiefoundation.org/Classification/index.htm.

12. The Boyer Commission on Educating Undergraduates. Reinventing Undergraduate Education: A Blueprint for America's Research Universities, 1998 [online] available from http://notes.cc.sunysb.edu/Pres/boyer.nsf [cited 25 October 2000].

13. See Patrick Terenzini and Ernest Pascarella, How College Affects Students: Findings and Insights from Twenty Years of Research (San Francisco: Jossey-Bass, 1991).

14. Laura J. Horn and Xianglei Chen, Toward Resiliency: At-Risk Students Who Make it to College (Washington, DC: U.S. Department of Education, Office of Research and Improvement, May 1998); Laura Horn, Confronting the Odds: Students at Risk and the Pipeline to Higher Education (Washington, DC: National Center for Educational Statistics, 1997); Clifford Adelman, Answers in the Tool Box: Academic Intensity, Attendance Patterns, and Bachelor's Degree Attainment (Washington, DC: US Department of Education, Office of Educational Improvement, 1999); Patrick T. Terenzini, Leonard Springer, Patricia M. Yaeger, Ernest T. Pascarella, and Amaury Nora, "First-Generation College Students: Characteristics, Experiences, and Cognitive Development," Research in Higher Education 37 (February 1996): 1617.

15. Julie Noble, Mark Davenport, Jeff Schiel, and Mary Pommerich, "Relationships Between the Noncognitive Characteristics, High School Course Work and Grades, and Test Scores of ACT-Tested Students," ACT Research Report 99-4, 1999; Julie Noble, Mark Davenport, Jeff Schiel, and Mary Pommerich, "High School Academic and Noncognitive Variables Related to the ACT Scores of Racial/Ethnic and Gender Groups." ACT Research Report 99-6, 1999.

16. Noble et al., "Relationships Between the Noncognitive Characteristics." 17. Adelman, Answers in the Tool Box, ix.

18. Ibid.

19. Jonathan Kozol, Savage Inequalities: Children in America's Schools (New York: HarperPerennial, 1992).

20. Terenzini et al., "First-Generation College Students."

21. The College Board, Reaching the Top, 31-32; Charles Woolston, Freeman A. Hrabowski, and Kenneth I. Maton, "The Recruitment and Retention

Journal of Library Administration, Vol 33, No. 1/2 (2001): pg. 5-19. DOI. This article is @ Taylor \& Francis (Routledge) and permission has been granted for this version to appear in e-Publications@Marquette. Taylor \& Francis (Routledge) does not grant permission for this article to be further copied/distributed or hosted elsewhere without the express permission from Taylor \& Francis (Routledge) 
of Talented African Americans in Science: The Role of Mentoring," Diversity in Higher Education 1 (1977): 103-14; L. Scot Miller, "Promoting High Academic Achievement among Non-Asian Minorities," in Promise and Dilemma, 74-81.

22. The TRIO programs include eight outreach and support programs targeted to help disadvantaged students progress from middle school to postbaccalaureate programs. TRIO began with Upward Bound, which emerged out of the Economic Opportunity Act of 1964; in 1965, Talent Search, the second outreach program, was created as part of the Higher Education Act; in 1968, Student Support Services, which was originally known as Special Services for Disadvantaged Students, was authorized by the Higher Education Amendments and became the third in a series of educational opportunity programs. By the late 1960s, the term "TRIO" was coined to describe these federal programs. See Federal TRIO Programs [online] available from http://www. ed.gov/offices/OPE/HEP/trio/ [cited 6 November 2000].

23. Sylvia Hurtado, "The Institutional Climate for Talented Latino Students," Research in Higher Education 35 (February 1994): 21-41; see also Sylvia Hurtado, Jeffrey Milem, Alma Clayton-Pederson, and Walter Allen, Enacting Diverse Learning Environments: Improving the Climate for Racial/Ethnic Diversity in Higher Education (ASHE-ERIC Higher Education Report, 26/8, 1999).

24. Alberto F. Cabrera, Amaury Nora, and Patrick T. Terenzini, "Campus Racial Climate and the Adjustment of Students to College: A Comparison Between White Students and African-American Students," Journal of Higher Education 70 (March-April, 1999): 134-60.

25. Claude Steele, "A Threat in the Air: How Stereotypes Shape Intellectual Identity and Performance," in Promise and Dilemma, 94.

26. Charles Healy, "An Operational Definition of Mentoring," Diversity in Higher Education 1 (1997): 10.

27. Faculty mentoring programs are now common at colleges and universities. The Mellon Foundation funds programs at a number of selective institutions, and others, such as the University of Michigan, Michigan State University, the University of Minnesota, and the University of Maryland-Baltimore County, have created mentoring programs. The U.S. Department of Education funds approximately 160 Ronald McNair Scholars programs, which are designed to create faculty mentoring relationships for minority and low-income/first-generation students. Mentoring as a strategy has been recognized by the White House through creation of the Presidential Awards for Excellence in Science, Mathematics and Engineering Mentoring.

28. Bowen and Bok, The Shape of the River.

Journal of Library Administration, Vol 33, No. 1/2 (2001): pg. 5-19. DOI. This article is @ Taylor \& Francis (Routledge) and permission has been granted for this version to appear in e-Publications@Marquette. Taylor \& Francis (Routledge) does not grant permission for this article to be further copied/distributed or hosted elsewhere without the express permission from Taylor \& Francis (Routledge). 
29. Enhancing the Minority Presence in Graduate Education V: Summer Research Opportunity Programs, Voices and Visions of Success in Pursuit of the Ph.D. (Washington, DC: Council of Graduate Schools, 1993); "U. of Maryland Branch is Beacon for Minorities in Math and Science," New York Times, 14 October 2000.

30. Programs at a Glance: The Ronald G. McNair Postbaccalaureate

Achievement [online] available from http://www.trioprograms.org [cited 25 October 2000].

31. Miller, "Promoting High Academic Achievement," 78-79.

32. See Brent Staples, "Preaching the Gospel of Academic Excellence," New York Times, 5 June 2000, sec A, p. 40.

33. Terenzini and Pascarella, How College Affects Students.

34. Carol Kuhlthau, "The Process of Learning from Information," in The Virtual School Library: Gateway to the Information Superhighway, ed. Carol Collier Kuhlthau (Englewood, CO: Libraries Unlimited, 1996), 103.

35. Patricia Senn Breivik, "Education for the Information Age," in Information Literacy: Developing Students as Independent Learners (San Francisco: Jossey-Bass, 1992): 8.

36. As a result of their efforts, the library was asked to submit a letter of support for renewal of the Upward Bound grant proposal, highlighting their role in contributing to the information competencies of student participants.

37. Council for Equal Opportunity in Education [online] available from http://www.trioprograms.org/home.html [cited 25 October 2000].

38. Enhancing the Minority Presence.

39. Tom Holt, Thinking Historically: Narrative, Imagination, and Understanding (New York: The College Board, 1995), 54. 